Research Article

\title{
Phytochemical and Cytotoxic Test of Durio kutejensis Root Bark on MCF-7 Cells
}

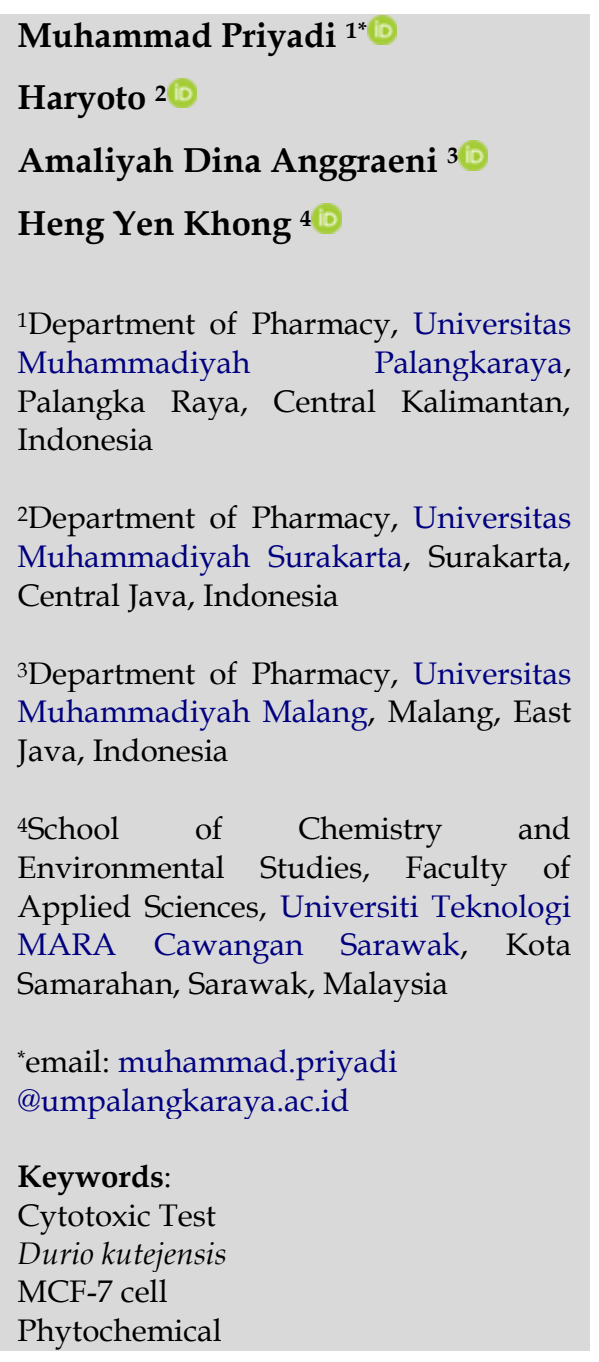

\begin{abstract}
Durio kutejensis has known potential as herbal medicine in Kalimantan. Many things can be explored from D. kutejensis related pharmacological activity in every part of the plant included root bark. This study investigated the phytochemical content with a qualitative test and tested cytotoxic activities of D. kutejensis root bark on MCF-7 cell lines. Cytotoxic activity tested on MCF-7 cells with MTT assay method. The result showed that D. kutejensis root bark contains flavonoid, tannin, terpenoid, phenol, and saponin. $\mathrm{IC}_{50}$ value for ethanol extracts of root bark, $n$-hexane fractions, ethyl acetate fractions, and doxorubicin on MCF-7 cells were 761.29; 280.5; 207.08; and $0.25 \mu \mathrm{g} / \mathrm{mL}$, respectively. In conclusion, D. kutejensis root bark has some secondary metabolites but no cytotoxic activity on MCF-7 cells. Further research is needed to explore the anticancer activity of secondary metabolites on some other cancer cells and other pharmacological activities.
\end{abstract}

Received: June $6^{\text {th }}, 2020$

Accepted: December 25th, 2020

Published: February 28th, 2021

(c) 2021 Muhammad Priyadi, Haryoto, Amaliyah Dina Anggraeni, Heng Yen Khong. Published by Institute for Research and Community Services Universitas Muhammadiyah Palangkaraya. This is an Open Access article under the CC-BY-SA License (http://creativecommons.org/licenses/by-sa/4.0/). DOI: https://doi.org/10.33084/bjop.v4i1.1443

\section{INTRODUCTION}

Many products of natural medicines from plants with secondary metabolites have potential as anticancer and are used clinically ${ }^{1,2}$. Durio kutejensis is known as lai, durian kenyak, durian pulu, paken, and pampaken in Kalimantan. Kalimantan people usually use fruits and its flower for consumption and traditional medicine ${ }^{3}$. Durio kutejensis contains terpenoid, tannin, and phenols ${ }^{46}$. Previously, $D$. kutejensis leaves were tested its activity as antioxidant ${ }^{7,8}$, and stem bark of $D$. kutejensis has potential as antidiabetic activities'. Some genus of Durio, such as Durio zibethinus and Durio affinis, were tested on MCF-7, T47D, and HeLa cells for anticancer activity ${ }^{10,11}$. However, there is no research before on root bark for secondary metabolite and its activity. This study aims to investigate its phytochemical and anticancer activities of D. kutejensis root bark on MCF-7 cell lines based on references. 


\section{MATERIALS AND METHODS}

\section{Materials}

Ethanol 96\%, silica gel $\mathrm{GF}_{254}$ plate (Merck), silica gel 60 (Merck), ethyl acetate (Merck), methanol, n-hexane, Mayer's, Wagner's, and Dragendorff's reagents, chloroform, $\mathrm{H}_{2} \mathrm{SO}_{4}, \mathrm{HCl}, \mathrm{FeCl}_{3}$, acetic acid, MCF-7 cells, phosphate buffered saline (PBS) (Gibco), MTT solution, SDS 10\%, DMSO 1\%, Dulbecco's Modified Eagle's Medium (DMEM), and trypsin-EDTA 0.25\% (Gibco).

\section{Methods}

\section{Extraction and fractionation}

The root bark of D. kutejensis was collected from Pulang Pisau, Central Kalimantan, as shown in Figure 1. The plant sample was determined at the Laboratory of Biology Department, Universitas Negeri Sebelas Maret (No. 209/UN27.9.6.4/Lab/2017). The root bark was cleaned, chopped, dried in sunlight, and powdered. Root bark $(5 \mathrm{~kg})$ was extracted with ethanol $96 \%$ for three days by the maceration method. The filtrate was filtered and evaporated with a rotary evaporator at $50^{\circ} \mathrm{C}$.

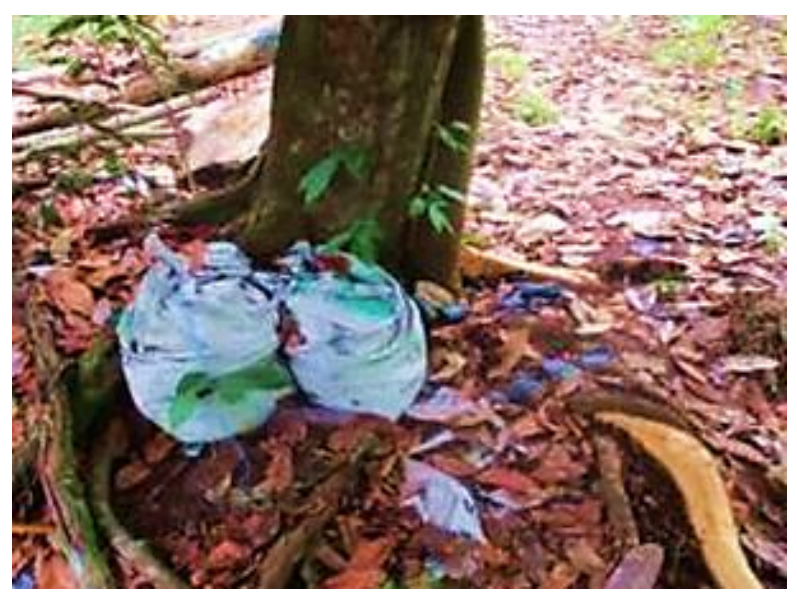

Figure 1. Root bark of D. kutejensis

A schematic of the extraction and fractionation processes was presented in Figure 2. As much as $30 \mathrm{~g}$ of ethanol extract was fractionated using hexane and ethyl acetate solvents with a liquid-liquid partition. The extract was dissolved first with $50 \mathrm{~mL}$ ethanol solvent and put into a separating funnel. Then, ethyl acetate and hexane were mixed with a volume of $50 \mathrm{~mL}$ and then shaken. The mixture was allowed to stood for some time and separate to hexane fraction on the top, ethyl acetate fraction in the middle, and the bottom as ethanol. The layers were separated using a separating funnel that was carefully accommodated, and the partitioning process was repeated 2-3 times. The result of partition separation was evaporated and weighed.

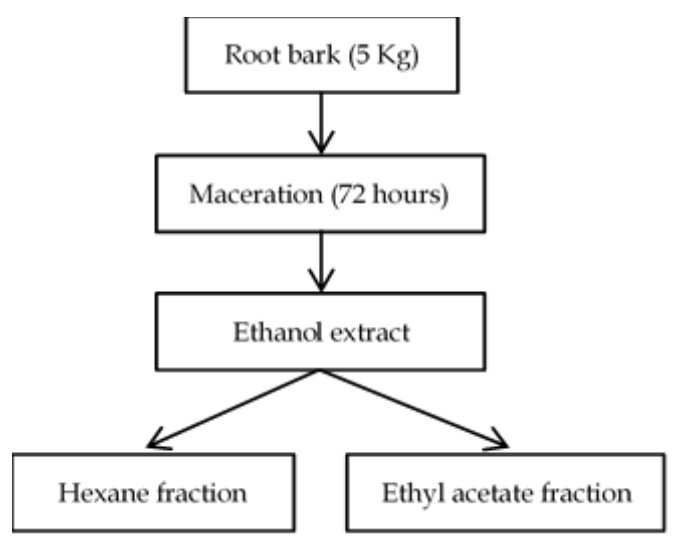

Figure 2. Extraction and fractionation process scheme of $D$. kutejensis

\section{Phytochemical screening}

The ethanol extract was tested by a qualitative test with the procedure as reported by previous studies 12,13 as follows:

1. Alkaloid test

Mayer's test: The extract was treated with Mayer's reagent and will form a yellow cream precipitate.

Wagner's test: The extract was treated with Wagner's reagent and will form a brown or reddish-brown precipitate.

Dragendorff's test: The extract was sprayed or dropped with a small Dragendorff's reagent and will show an orange spot.

2. Terpenoid test

Salkowski's test: As much as $5 \mathrm{mg}$ of the extract was mixed with $2 \mathrm{~mL}$ of chloroform, and $3 \mathrm{~mL}$ of concentrated $\mathrm{H}_{2} \mathrm{SO}_{4}$ was carefully added to form a layer. It will show an appearance of reddish-brown color in the inner face. 


\section{Flavonoid test}

Shinoda's test: A piece of magnesium ribbon and 1 $\mathrm{mL}$ of concentrated $\mathrm{HCl}$ was added to the extract. It will show the pink-red or red coloration of the solution.

$\mathrm{H}_{2} \mathrm{SO}_{4}$ test: The extracts were treated with few drops of $\mathrm{H}_{2} \mathrm{SO}_{4}$ and will form orange color.

4. Phenol test

$\mathrm{FeCl}_{3}$ test: About $10 \mathrm{mg}$ of extracts were treated with few drops of $\mathrm{FeCl}_{3}$ solution and will show the formation of bluish-black color.

5. Saponin test

Frothing/Foam test: About $0.5 \mathrm{mg}$ of the extract was shaken with $0.5 \mathrm{~mL}$ distilled water and will form frothing or some bubbles for a long time.

6. Steroid test

Liebermann-Burchard test: The extract was added with $1 \mathrm{~mL}$ of chloroform, 2-3 $\mathrm{mL}$ of acetic acid anhydride, 1-2 drops of concentrated $\mathrm{H}_{2} \mathrm{SO}_{4}$, and will show the dark green coloration.

7. Tannin test

Braemer's test: A small extract was mixed with distilled water and heated in a water bath. Then filtered and added some $\mathrm{FeCl}_{3}$. A dark green color will form as the presence of tannins.

\section{Cytotoxic assay}

The MCF-7 cells were cultured in the Laboratory of Pharmaceutical Biology, Universitas Muhammadiyah Surakarta. For incubation, DMEM was used as a medium after adding 10\% PBS, 2\% penicillin/streptomycin, and $0.5 \%$ fungizone. Cell lines were adapted and subcultured in mediums at $37^{\circ} \mathrm{C}$ and $5 \% \mathrm{CO}_{2}$ incubator. The cell lines were then added with the extract, $n$-hexane fraction, ethyl acetate fraction (triplicate). Doxorubicin was used as a comparison for positive control. After 48 hours of incubation for MCF-7, MTT reagent was added and incubated in a $\mathrm{CO}_{2}$ incubator for 2 to 4 hours at $37^{\circ} \mathrm{C}$. Then, $100 \mu \mathrm{LSDS} 10 \%$ was added in $0.01 \mathrm{~N} \mathrm{HCl}$ and stored in a dark place (covered with aluminum foil) overnight. The absorbance results were checked with an ELISA reader at wavelengths $594 \mathrm{~nm}$. After that, \% cell viability was calculated with the following equation:

$\%$ Cell viability $=\frac{\text { Absorbance of } \text { sample-Absorbance of control media }}{\text { Absorbance of control cell }- \text { Absorbance of control media }} \times 100 \%$

The $\mathrm{IC}_{50}$ value was calculated with Microsoft Excel 2010. The value of $\mathrm{IC}_{50}$ is obtained by the probit $\log$ calculation with $y=b x+a$, where $y$ is $\%$ cell viability, and $x$ is log concentration.

\section{RESULTS AND DISCUSSION}

\section{Extraction and fractionation}

The ethanol extract obtained was $123 \mathrm{~g}$ with the ethyl acetate and the $n$-hexane fraction obtained was $2.17 \mathrm{~g}$ and $0.89 \mathrm{~g}$, respectively. According to the result, ethanol solvent was quite effective in extracting secondary metabolites and was commonly carried out, especially for extract polar, semipolar, and non-polar metabolites ${ }^{14}$. Previous research on D. kutejensis also carried out the extraction of plant parts using ethanol, $n$-hexane, and ethyl acetate solvents 8 .

\section{Phytochemical screening}

The result showed that ethanol could extract various compounds from D. kutejensis, as presented in Table I. The ethanol solvent was known to extracts various polar, semipolar, to non-polar compounds in a plant ${ }^{14}$. Previous research also showed that D. kutejensis contains terpenoid, tannin, and phenols ${ }^{4-6}$.

\section{Cytotoxic assay}

The $\mathrm{IC}_{50}$ value for ethanol extracts of root bark, $n$-hexane, and ethyl acetate fractions on MCF-7 cells were 761.29; 280.5; and 207.08 $\mu \mathrm{g} / \mathrm{mL}$, respectively. The extract had the highest $\mathrm{IC}_{50}$ value, while the lowest is ethyl acetate 
fraction, which shows that the fraction had better cytotoxic activity than the extract. The possible cause was because the fraction contains certain compounds in a higher concentration than the extract ${ }^{15}$. The solvent in the extraction process could affect some compound content in the extract. Ethyl acetate, as a semipolar solvent, could dissolve steroids and alkaloids and effectively extract steroids, terpenoids, and flavonoids. Simultaneously, nhexane solvents were effective for non-polar metabolites such as steroids and terpenoids ${ }^{14}$. However, the $\mathrm{IC}_{50}$ values shown by the three were still much lower than doxorubicin at only $0.25 \mu \mathrm{g} / \mathrm{mL}$, as shown in Table II.

The cytotoxic test showed that the anticancer activity of ethanol extract, ethyl acetate, and $n$-hexane fraction was included in the inactive category $\left(\mathrm{IC}_{50}>100 \mu \mathrm{g} / \mathrm{mL}\right)$ based on The National Cancer Institute (NCI) category ${ }^{16,17}$. Previously, research on an ethanol extract of D. affinis on T47D cells and HeLa cells had $\mathrm{IC}_{50}$ values of 828.3 and $300.5 \mu \mathrm{g} / \mathrm{mL}$, respectively ${ }^{11}$. The research showed that the ethanol extract of $D$. kutejensis root bark had no anticancer activity against MCF-7 cells.

Table I. Phytochemical screening of D. kutejensis root bark extract

\begin{tabular}{llc}
\hline \multicolumn{1}{c}{ Phytochemicals } & \multicolumn{1}{c}{ Method/Test } & Result \\
\hline Alkaloid & Mayer's test & - \\
& Wagner's test & - \\
& Dragendorff's test & - \\
Terpenoid & Salkowski's test & + \\
Flavonoid & $\mathrm{Shinoda's} \mathrm{test}$ & + \\
Phenol & $\mathrm{H}_{2} \mathrm{SO}_{4}$ test & + \\
Saponin & $\mathrm{FeCl}_{3}$ test & + \\
Steroid & Frothing/Foam test & - \\
Tannin & Liebermann-Burchard test & + \\
\hline
\end{tabular}

Table II. The IC 50 values of D. kutejensis root bark on MCF-7 cells

\begin{tabular}{lc}
\hline \multicolumn{1}{c}{ Sample } & $\mathrm{IC}_{50} \pm \mathrm{SD}(\mu \mathrm{g} / \mathrm{mL})$ \\
\hline Ethanol extract & $761.29 \pm 6.06$ \\
$n$-hexane fraction & $280.5 \pm 3.05$ \\
Ethyl acetate fraction & $207.08 \pm 3.82$ \\
Doxorubicin & $0.25 \pm 0.12$ \\
\hline
\end{tabular}

\section{CONCLUSION}

In conclusion, D. kutejensis root bark contains flavonoid, tannin, terpenoid, phenol, and saponin. However, D. kutejensis root bark had no potential activity against MCF7 cells. Further research was needed to explore the anticancer activity of secondary metabolites on some other cancer cells as well as for other pharmacological activities.

\section{ACKNOWLEDGMENT}

The authors thank Allah SWT, family, Pharmacy Faculty of Universitas Muhammadiyah Surakarta, and Faculty of Applied Sciences, Universiti Teknologi MARA, Sarawak, for the facilities and accommodations in this research.

\section{REFERENCES}

1. Solowey E, Lichtenstein M, Sallon S, Paavilainen H, Solowey E, Lorberboum-Galski H. Evaluating medicinal plants for anticancer activity. ScientificWorldJournal. 2014;2014:721402. doi:10.1155/2014/721402

2. Prakash O, Kumar A, Kumar P, Ajeet. Anticancer Potential of Plants and Natural Products: A Review. Am J Pharmacol Sci. 2013;1(6):104-15. doi:10.12691/ajps-1-6-1

3. Atmoko T. Potensi dan Konservasi Durian Hutan Kalimantan (Durio kutejensis). In: Soemargono A, editor. Prosiding Seminar Nasional Buah Tropika Nusantara II: Dukungan Teknologi dan Hasil Penelitian dalam Membangun Pembangunan BioIndustri Buah Tropika Berkelanjutan [Internet]; 2014 Sep 23-25; Bukittinggi. Solok: Balai Penelitian Tanaman Buah Tropika; 2015. p. 437-46.

4. Gorinstein S, Poovarodom $S$, Leontowicz $H$, Leontowicz M, Namiesnik J, Vearasilp, et al. Antioxidant properties and bioactive constituents of some rare exotic Thai fruits and comparison with conventional fruits: In vitro and in vivo studies. Food Res Int. 2011;44(7):2222-32. doi:10.1016/j.foodres.2010.10.009

5. Sardans J, Llusia J, Owen SM, Niinemets Ü, Peñuelas J. Screening Study of Leaf Terpene Concentration of 75 Borneo Rainforest Plant Species: Relationships with Leaf Elemental Concentrations and Morphology. Rec Nat Prod. 2015;9(1):19-40. 
6. Khoo HE, Azlan A, Kong KW, Ismail A. Phytochemicals and Medicinal Properties of Indigenous Tropical Fruits with Potential for Commercial Development. Evid Based Complement Alternat Med. 2016;2016:7591951. doi:10.1155/2016/7591951

7. Ikram EHK, Eng KH, Jalil AMM, Ismail A, Idris S, Azlan A, et al. Antioxidant capacity and total phenolic content of Malaysian underutilized fruits. J Food Compos Anal. 2009;22(5):388-93. doi:10.1016/j.jfca.2009.04.001

8. Arung T, Suwinarti W, Hendra M, Supomo S, Kusuma IW, Puteri DCN, et al. Determination of Antioxidant and Anti-Melanogenesis Activities of Indonesian Lai, Durio kutejensis [Bombacaceae (Hassk) Becc] Fruit Extract. Trop J Pharm Res. 2015;14(1):41-6. doi:10.4314/tjpr.v14i1.7

9. Yusro F, Ohtani K, Kubota S. Inhibition of aGlucosidase by Methanol Extracts from Wood Bark of Anacardiaceae, Fabaceae, Malvaceae and Phyllanthaceae Plants Family in West Kalimantan, Indonesia. Kuroshioken Kagaku. 2016;9(2):108-22.

10. Jayakumar R, Kanthimathi MS. Inhibitory effects of fruit extracts on nitric oxide-induced proliferation in MCF-7 cells. Food Chem. 2011;126(3):956-60. doi:10.1016/j.foodchem.2010.11.093

11. Rudiyansyah, Masriani, Mudianta IW, Garson MJ. Isolation and Absolute Configuration of Boehmenan from Durio affinis Becc. Rec Nat Prod. 2014;8(2):1958.

12. Santhi K, Sengottuvel R. Qualitative and Quantitative Phytochemical analysis of Moringa concanensis Nimmo. Int J Curr Microbiol App Sci. 2016;5(1):63340. doi:10.20546/ijcmas.2016.501.064

13. Sasidharan S, Chen $Y$, Saravanan D, Sundram KM, Latha LY. Extraction, Isolation and Characterization of Bioactive Compounds from Plants' Extracts. Afr J Tradit Complement Altern Med. 2011;8(1):1-10.

14. Widyawati PS, Budianta TDW, Kusuma FA, Wijaya EL. Difference of Solvent Polarity to Phytochemical Content and Antioxidant Activity of Pluchea indicia Less Leaves Extracts. Int J Pharmacogn Phytochem Res. 2014;6(4):850-5.

15. Altemimi A, Lakhssassi N, Baharlouei A, Watson DG, Lightfoot DA. Phytochemicals: Extraction, Isolation, and Identification of Bioactive Compounds from Plant Extracts. Plants. 2017;6(4):42. doi:10.3390/plants6040042

16. Vijayarathna S, Sasidharan S. Cytotoxicity of methanol extracts of Elaeis guineensis on MCF-7 and Vero cell lines. Asian Pac J Trop Biomed. 2012;2(10):826-9. doi:10.1016/s2221-1691(12)60237-8

17. Çoruh N, Özdoğan N. Wild-growing Rosa heckeliana Tratt:: phenolic constituents with cytotoxic and antioxidative properties. Turk J Biol. 2017;41:195212. doi:10.3906/biy-1605-89 